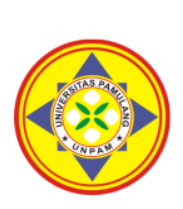
PERTUSS

\title{
PENGARUH KUALITAS PRODUK, KUALITAS INFORMASI DAN KEPERCAYAAN PELANGGAN TERHADAP MINAT BELI ONLINE DI LAZADA
}

\author{
${ }^{*}$ Adi Suparwo, ${ }^{2}$ Penny Rahmadewi \\ Universitas ARS Bandung, Jawa Barat, Indonesia \\ *adi.suparwo@ars.ac.id
}

\begin{abstract}
Abstrak
Penelitian ini bertujuan untuk mengetahui pengaruh antara variabel kualitas produk, kualitas informasi, dan kepercayaan pelanggan terhadap minat beli online di Lazada teknik pengambilan sampel menggunakan simple random sampling dengan jumlah responden sebanyak 100 orang. Analisis data menggunakan analisis deskriptif dan analisis verifikatif serta metode penelitian menggunakan metode kuantitatif. Hasil penelitian menunjukkan bahwa kualitas produk berpengaruh positif dan signifikan terhadap minat beli, kualitas informasi berpengaruh positif dan signifikan terhadap minat beli, dan kepercayaan pelanggan berpengaruh positif dan signifikan terhadap minat beli. Pengujian secara simultan hasil menunjukkan kualitas produk, kualitas informasi, dan kepercayaan pelanggan berpengaruh signifikan terhadap minat beli. Berdasarkan hasil temuan pada penelitian bahwa perusahaan yang memberikan kualitas produk, kualitas informasi dan kepercayaan pelanggan yang baik akan meningkatkan minat beli.
\end{abstract}

Kata Kunci: Kualitas Produk, Kualitas Informasi, Kepercayaan Pelanggan, Minat Beli

\section{Abstract}

This study aims to determine the effect of product quality, information quality, and customer trust on online buying interest at Lazada. The sampling technique used is simple random sampling with a total of 100 respondents. Data analysis used descriptive analysis and verification analysis and research methods used quantitative methods. The results showed that product quality had a positive and significant effect on buying interest, information quality had a positive and significant effect on buying interest, and customer trust had a positive and significant effect on buying interest. Simultaneous test results show product quality, information quality, and customer trust have a significant effect on buying interest. Based on the findings in the study that companies that provide good product quality, information quality and costomer trust will increase buying interest. Keywords: Product Quality, Information Quality, Customer Trust, Buying Interest

\section{PENDAHULUAN}

\section{A. Latar Belakang}

Perkembangan teknologi informasi yang sangat pesat membawa dampak yang besar bagi segala aspek termasuk internet, hal ini termasuk juga pada perkembangan dunia bisnis dan pemasaran. Saat ini sudah sangat banyak orang yang memanfaatkan internet sebagai media bisnis dan pemasaran. Hal ini mengingat jumlah pengguna internet yang terus bertambah pesat dapat menjadi sebuah pasar yang tersembunyi untuk dimasuki para pebisnis. Dengan semakin meningkatnya pengguna internet di Indonesia, hal ini menjadikan peluang bisnis baru bagi beberapa pihak yang kemudian memahami peluang tersebut dengan menyediakan atau membuat toko online sebagai bagian dari $E$ Commerce. E-Commerce merupakan istilah yang mengarahkan secara khusus pada pertukaran bisnis atau transaksi yang terjadi secara elektronik. E-Commerce meningkatkan pertukaran uang dan produk dengan data dan informasi dari suatu komputer ke komputer lain (Wijaya \& Kempa, 2018).

Salah satu situs website E-Commerce yang membawa konsep E-Marketplace ialah Lazada. Lazada merupakan situs belanja online yang menawarkan berbagai macam jenis produk, mulai dari produk kecantikan,peralatan rumah tangga, elektronik, buku-buku, mainan anak, 
perlengkapan bayi, alat kesehatan, serta perlengkapan traveling dan olahraga. Belanja online memiliki beberapa keuntungan atas belanja tradisional salah satunya yaitu pembelanjaan secara online dapat diakses dengan jangkauan yang luas, kapan saja dan dimana saja sehingga konsumen tidak perlu menyempatkan waktunya untuk belanja produk, melainkan konsumen dapat berbelanja sambil melakukan kegiatan lain. Lazada Indonesia didirikan pada tahun 2012 dan merupakan bagian dari Lazada Group yang beroperasi di Asia Tenggara. Dengan toko yang berbasis pada dunia virtual yang tidak mempertemukan penjual dan pembeli secara langsung maka akan ada faktorfaktor yang mempengaruhi seseorang untuk melakukan transaksi belanja online (Mulyadi et al., 2018).

Pemberlakuan Work From Home (WFH) juga berdampak pada minat beli secara online. Minat beli secara online biasanya banyak dilakukan oleh konsumen remaja karena golongan mereka inilah yang banyak menggunakan fasilitas online untuk memenuhi kebutuhannya meskipun tidak sedang dalam kondisi Covid-19. metode belanja yang disukai remaja saat ini ialah metode hedonic shopping dimana kehidupan remaja yang cenderung lebih menyukai dan mengutamakan kesenangan semata saat berbelanja online. Tetapi dengan kondisi seperti ini, dengan adanya Covid-19 pembelian secara online tidak hanya dilakukan oleh remaja tetapi juga semua kelompok usia karena untuk memenuhi kebutuhannya (Amil et al., 2020)

Tabel 1. Pengunjung Yang Membeli Produk Di Lazada

\begin{tabular}{|c|c|c|}
\hline No & $\begin{array}{c}\text { Data Per } \\
\text { kuartal }\end{array}$ & $\begin{array}{c}\text { Pengunjung Yang } \\
\text { Membeli }\end{array}$ \\
\hline 1 & Q4 2018 & 58.288 .400 Orang \\
\hline 2 & Q1 2019 & 52.044 .500 Orang \\
\hline 3 & Q2 2019 & 49.620 .200 Orang \\
\hline 4 & Q3 2019 & 27.995 .900 Orang \\
\hline 5 & Q4 2019 & 28.383 .300 Orang \\
\hline 6 & Q1 2020 & 24.400 .000 Orang \\
\hline 7 & Q2 2020 & 22.021 .800 Orang \\
\hline 8 & Q3 2020 & 22.674 .700 Orang \\
\hline 9 & Q4 2020 & 36.260 .600 Orang \\
\hline
\end{tabular}

Data tabel 1. menunjukkan bahwa pengunjung bulanan Lazada dari tahun 2018 sampai 2020 mengalami penurunan. Dapat dilihat pengunjung bulanan pada Q2 2019 sebanyak 49.620.200, sedangkan pada Q3 2019 terjadi penurunan yang cukup drastis dengan jumlah pengunjung 27.995.900. Data tersebut menunjukkan bahwa minat pengunjung Lazada berkurang, sehingga bepengaruh terhadap minat beli online di Lazada.

$$
\text { Kegiatan perusahaan dalam }
$$
memahami perilaku konsumen sangat perlu dilakukan untuk mempengaruhi minat beli. Tidak mudah dalam mengetahui sikap konsumen karena konsumen sangat beragam mulai dari tingkat pendapatan, usia, selera, dan pendidikan sehingga dalam memberikan keputusan pembelianpun berbeda. Minat beli konsumen selalu tersembunyi dalam tiap diri individu yang tak seorang pun tahu apa yang diinginkan dan diharapkan oleh konsumen. Menurut Kotler mengenai minat beli "sebelum merencanakan untuk membeli produk maka ada proses atau tahap terdahulu yang dilakukan konsumen adalah minat beli" (Suparwo \& Pratama, 2021).

Salah satu faktor yang menentukan minat beli yaitu kualitas produk. Kualitas produk juga berperan penting dalam jualbeli secara online. Kualitas produk menggambarkan kemampuan produk untuk menjalankan tugasnya yang mencakup daya tahan, kehandalan atau kemajuan, kekuatan, kemudahan dalam pengemasan dan reparasi produk dan ciriciri lainnya (Kotler dan Amstrong,1997) dalam (Bahar \& Sjahruddin, 2017). Produk dinilai penting oleh konsumen dan dijadikan dasar minat beli konsumen. Kualitas produk (product quality) didefinisikan sebagai evaluasi menyeluruh pelanggan atas kebaikan kinerja barang atau jasa (Mowen dan Minor dalam (Yazia, 2014).

Faktor lain yang menentukan minat beli antara lain yaitu kualitas informasi. Dalam sebuah situs jual beli online, agar muncul minat beli dari calon konsumen 
maka penjual harus memberlakukan informasi yang berkualitas. Informasi sangat diperlukan karena informasi merupakan data yang berguna bagi calon pembeli untuk mengambil keputusan (widhiani asterina, 2017).

Kepercayaan konsumen adalah satu kendala dalam melakukan online shopping, masih banyak konsumen yang masih tidak percaya dan merasa ragu dalam berbelanja berbasis online, hal itu menjadi kendala untuk para pelaku usaha E-commerce. Para pelaku E-commerce harus memberikan pelayanan dan kualitas yang baik agar dapat menciptakan kepercayaan pada setiap pelanggannya. Pentingnya kepercayaan di suatu toko dalam transasksi di internet sangat terasa oleh para konsumen sehingga tak jarang hal ini menjadi salah satu indikator utama akan kepuasan dan niat konsumen untuk membeli suatu produk ditempat tertentu. Sebagai akibatnya perlu adanya rasa saling percaya antara pembeli dan penjual (Andhini \& Khuzaini, 2017).

Kepercayaan merupakan salah satu dari faktor psikologis dalam mempengaruhi perilaku konsumen. Dalam transaksi secara online, kepercayaan muncul ketika salah satu pihak yang terlibat telah mendapat kepastian dari pihak lainnya, serta mau dan bisa memberikan kewajibannya. Ketika seseorang berbelanja online, hal utama yang menjadi pertimbangan seorang pembeli adalah apakah website yang menyediakan online shop dan penjual online pada website tersebut dapat terpercaya, menurut Luarn dan Lin dalam (Yunita et al., 2016).

\section{B. Rumusan Masalah}

1. Bagaimana pengaruh kualitas produk terhadap minat beli online di Lazada?

2. Bagaimana pengaruh kualitas informasi terhadap minat beli online di Lazada?

3. Bagaimana pengaruh kepercayaan pelanggan terhadap minat beli online di Lazada?

4. Bagaimana pengaruh kualitas produk, kualitas informasi dan kepercayaan pelanggan terhadap minat beli online di Lazada?

\section{Tujuan Penelitian}

Adapun tujuan penelitian ini adalah:

1. Untuk menganalisis pengaruh kualitas produk terhadap minat beli online di Lazada

2. Untuk menganalisis pengaruh kualitas informasi terhadap minat beli online di Lazada

3. Untuk menganalisis pengaruh kepercayaan pelanggan terhadap minat beli online di Lazada

4. Untuk menganalisis pengaruh kualitas produk, kualitas informasi dan kepercayaan pelanggan terhadap minat beli online di Lazada

\section{TINJAUAN PUSTAKA}

\section{Minat Beli}

Meldarianda dan Lisan dalam

(Anwar \& Adidarma, 2016) menyimpulkan bahwa yang dimaksud dengan minat beli konsumen adalah suatu proses perencanaan pembelian suatu produk yang akan dilakukan oleh konsumen dengan mempertimbangakan beberapa hal, diantaranya adalah banyak unit produk yang dibutuhkan dalam periode waktu tertentu, merek, dan sikap konsumen dalam mengkonsumsi produk tersebut. Sementara itu, Nugraha (2013) menjelaskan bahwa minat beli diperoleh dari suatu proses belajar dan proses pemikiran yang membentuk suatu persepsi. Minat yang muncul dalam melakukan pembelian menciptakan suatu motivasi dan menjadi suatu kegiatan yang sangat kuat yang pada akhirnya ketika seorang konsumen harus memenuhi kebutuhanya akan mengaktualisasikan apa yang ada didalam benaknya itu. Minat membeli yang dilakukan dengan media online adalah keinginan seseorang untuk membeli suatu produk yang ditawarkan oleh produsen kepada konsumen melalui media online.

Menurut (Widiani et al., 2020) adapun indikator minat beli yaitu sebagai berikut :

1. Minat transaksional 
2. Minat referensial

3. Minat preferensial

4. Minat eksploratif

\section{Kualitas Produk}

Kualitas produk didefinisikan sebagai evaluasi menyeluruh pelanggan atas kebaikan kinerja barang atau jasa. Menurut Kotler dan Amstrong (2001) dalam (Bahar \& Sjahruddin, 2017) kualitas adalah karakteristik dari produk dalam kemampuan untuk memenuhi kebutuhan-kebutuhan yang telah ditentukan dan bersifat laten. Sedangkan produk adalah segala sesuatu yang dapat ditawarkan kepasar untuk mendapatkan perhatian, dibeli, digunakan, atau dikonsumsi yang dapat memuaskan keinginan atau kebutuhan. Kualitas produk juga berperan penting dalam jual-beli secara online. Menurut (Kotler dan Amstrong 2001) dalam (Arum, 2013). Kualitas produk mencerminkan kemampuan produk untuk menjalankan tugasnya mencangkup daya tahan, kehandalan, atau kemajuan, kekuatan, kemudahan, dalam pengemasan reparasi produk dan ciri-cirinya.

Kotler dan Amstrong,1997; dalam (Bahar \& Sjahruddin, 2017) produk dipandang penting oleh konsumen dan dijadikan dasar minat beli konsumen. Dalam penelitian ini akan digunakan tiga indikator yang mencirikan percaya diri yaitu:

1. Keragaman ukuran produk

2. Fitur produk

3. Kejelasan fungsi.

4. Kemudahan Pengunaan

\section{Kualitas Informasi}

Kualitas informasi yaitu persepsi pelanggan terhadap suatu website mengenai kualitas informasi yang didapat (Park \& Kim dalam (Widiani et al., 2020)). Kualitas informasi merupakan kualitas yang berkaitan dengan jumlah, akurasi, dan bentuk informasi tentang produk dan jasa yang ditawarkan pada situs web. Kualitas informasi didefiniskan sebagai persepsi pelanggan terhadap kualitas informasi tentang produk atau layanan yang disediakan oleh sebuah website. Semakin berkualitas informasi yang diberikan kepada pembeli daring, maka akan semakin tinggi minat pembeli daring untuk membeli produk tersebut (Park, C.H dkk dalam (Gunawan \& Ayuningtiyas, 2018).

Indikator - indikator kualitas informasi antaralain :
1. Akurasi
2. Kelengkapan
3. Format (Bentuk)
4. Ketepatan waktu
5. Relevan

\section{Kepercayaan Pelanggan}

Mowen dan Minor (2002: 312) menyatakan kepercayaan konsumen adalah semua pengetahuan yang dimiliki oleh konsumen dan semua kesimpulan yang dibuat konsumen tentang objek, atribut, dan manfaatnya.(Bahrudin \& Zuhro, 2016) Kepercayaan merupakan pengetahuan kongnitif kita tentang sebuah objek, maka sikap merupakan tanggapan perasaan atau afektif yang kita miliki tentang objek. Berdasarkan (Peter and Olson, $2000: 157$ ) dalam (Bahrudin \& Zuhro, 2016).

Indikator kepuasan pelanggan sebagai berikut:

1. Perasaan senang menggunakan produk.

2. Cederung terus membeli.

3. Memberitahu orang lain tentang pengalaman menyenangkan dengan produk tersebut

\section{METODE PENELITIAN}

\section{Populasi}

Populasi yang digunakan dalam penelitian ini adalah pembeli Lazada pada tahun 2020 kuartal 4 sebanyak 36.260 .600 orang. Responden yang mengisi kuesioner yaitu masyarakat yang berada kota Bandung.

2. Sampel

Jumlah sampel dalam penelitian ini yaitu 
99,9 dibulatkan menjadi 100 responden.

\section{Jenis Penelitian}

Penelitian ini menggunakan metode deskriptif dan verifikatif dengan pendekatan kuantitatif. Metode desktiptif bertujuan untuk membuat deskripsi secara sistematis, actual, dan akurat mengenai fakta, sifat-sifat serta pengaruh antar fenomena yang diteliti (Sugiyono, 2017). Metode verifikatif digunakan untuk meneliti ulang hasil penelitian sebelumnya dengan tujuan untuk memverifikasi kebenaran hasil penelitian sebelumnya (Sugiyono, 2017)

\section{Metode Analisis Data}

Dalam menganalisis data digunakan uji instrumen, uji asumsi klasik, regresi, koefisien korelasi, koefisien determinasi dan uji hipotesis.

\section{HASIL PENELITIAN DAN PEMBAHASAN}

\section{Uji Validitas}

Tabel 2. Hasil Uji Validitas

\begin{tabular}{|c|c|c|c|}
\hline Variabel & $\mathbf{r}_{\text {hitung }}$ & $\mathbf{r}_{\text {tabel }}$ & Keterangan \\
\hline \multirow{5}{*}{ Kulitas Produk } & 0,816 & 0,3 & Valid \\
\hline & 0,833 & 0,3 & Valid \\
\hline & 0,854 & 0,3 & Valid \\
\hline & 0,842 & 0,3 & Valid \\
\hline & 0,839 & 0,3 & Valid \\
\hline \multirow{7}{*}{$\begin{array}{l}\text { Kualitas } \\
\text { Informasi }\end{array}$} & 0,806 & 0,3 & Valid \\
\hline & 0,871 & 0,3 & Valid \\
\hline & 0,807 & 0,3 & Valid \\
\hline & 0,817 & 0,3 & Valid \\
\hline & 0,844 & 0,3 & Valid \\
\hline & 0,837 & 0,3 & Valid \\
\hline & 0,806 & 0,3 & Valid \\
\hline \multirow{3}{*}{$\begin{array}{c}\text { Kepercayaan } \\
\text { Pelanggan }\end{array}$} & 0,835 & 0,3 & Valid \\
\hline & 0,855 & 0,3 & Valid \\
\hline & 0,882 & 0,3 & Valid \\
\hline \multirow{8}{*}{ Minat Beli } & 0,778 & 0,3 & Valid \\
\hline & 0,803 & 0,3 & Valid \\
\hline & 0,807 & 0,3 & Valid \\
\hline & 0,847 & 0,3 & Valid \\
\hline & 0,863 & 0,3 & Valid \\
\hline & 0,843 & 0,3 & Valid \\
\hline & 0,849 & 0,3 & Valid \\
\hline & 0,868 & 0,3 & Valid \\
\hline
\end{tabular}

Pada tabel 2, menunjukkan bahwa setiap pernyataan variabel kualitas produk, kualitas informasi, kepercayan pelanggan dan minat beli dalam penelitian ini dikatakan valid karena nilai $r_{\text {hitung }}$ lebih besar dari $r_{\text {tabel }}(0,3)$.

\section{Uji Reliabilitas}

Dalam pembahasan ini adalah hasil uji reliabilitas instrumen dengan pengolahandata menggunakan SPSS

Tabel 3. Hasil Uji Reliabilitas

\begin{tabular}{|c|c|c|c|}
\hline Variabel & $\begin{array}{c}\text { Koefisie } \\
\mathbf{n}\end{array}$ & $\begin{array}{c}\text { Cronbac } \\
\text { h's } \\
\text { Alpha }\end{array}$ & $\begin{array}{c}\text { Keteran } \\
\text { gan }\end{array}$ \\
\hline
\end{tabular}

\begin{tabular}{|c|c|c|c|}
\hline & $\begin{array}{c}\text { Reliabili } \\
\text { tas }\end{array}$ & & \\
\hline $\begin{array}{c}\text { Kualitas } \\
\text { Produk }\end{array}$ & 0,893 & 0,6 & Reliabel \\
\hline $\begin{array}{c}\text { Kualitas } \\
\text { Informasi }\end{array}$ & 0,922 & 0,6 & Reliabel \\
\hline $\begin{array}{c}\text { Kepercay } \\
\text { aan } \\
\text { Pelangga } \\
\mathrm{n}\end{array}$ & 0,819 & 0,6 & Reliabel \\
\hline $\begin{array}{c}\text { Minat } \\
\text { Beli }\end{array}$ & 0,936 & 0,6 & Reliabel \\
\hline
\end{tabular}

Hasil dari uji reliabilitas dalam penelitian ini menunjukkan bahwa variabel Kualitas Produk memiliki nilai 
0,893 untuk variabel Kualitas Informasi 0,922 untuk variabel Kepercayaan Pelanggan 0,819 dan untuk variabel Minat Beli 0,936. Maka dapat dinyatakan bahwa pernyataan dalam penelitian ini dinyatakan reliabel karena nilai lebih besar dari titik reliabel yakni 0,6.

\section{Uji Normalitas}

Tabel 4. Hasil Uji Normalitas

\begin{tabular}{|c|c|c|c|c|c|}
\hline \multicolumn{6}{|c|}{ One-Sample Kolmogorov-Smirnov Test } \\
\hline & & $\begin{array}{l}\text { Kualitas } \\
\text { Produk }\end{array}$ & \begin{tabular}{|l|} 
Kualitas \\
Informasi
\end{tabular} & \begin{tabular}{|c|} 
Kepercayaan \\
Pelanggan
\end{tabular} & $\begin{array}{l}\text { Minat } \\
\text { Beli }\end{array}$ \\
\hline \multicolumn{2}{|l|}{$\mathrm{N}$} & 100 & 100 & 100 & 100 \\
\hline \multirow{2}{*}{$\begin{array}{l}\text { Normal } \\
\text { Parameters }{ }^{\mathrm{a}, \mathrm{b}}\end{array}$} & Mean & 18.96 & 26.65 & 11.35 & 29.77 \\
\hline & $\begin{array}{l}\text { Std. } \\
\text { Deviation }\end{array}$ & 4.192 & 5.582 & 2.426 & 6.401 \\
\hline \multirow{3}{*}{$\begin{array}{l}\text { Most Extreme } \\
\text { Differences }\end{array}$} & Absolute & .228 & .255 & .196 & .234 \\
\hline & Positive & .098 & .119 & .106 & .097 \\
\hline & Negative & -.228 & -.255 & -196 & -.234 \\
\hline \multicolumn{2}{|l|}{ Test Statistic } & .228 & .255 & .196 & .234 \\
\hline \multicolumn{2}{|c|}{ Asymp. Sig. (2-tailed) } & $.060^{c}$ & .085 & .076 & $.100^{c}$ \\
\hline
\end{tabular}

Berdasarkan tabel 4, Asymp. Sig (2tailed) atau asymptotic significance pada kualitas produk 0,06, kualitas informasi 0,085 , kepercayaan pelanggan 0,076 , dan minat beli $0,100>0,05$ (level of significance), Maka dapat disimpulakan bahwa data berdistribusi normal. ehingga model regresi dapat dipakai karena memenuhi asumsi normalitas atau data berdistribusi normal.

4. Analisis Regresi Linier Berganda

Uji regresi ini dimaksudkan untuk mengetahui perubahan variabel dependen jika variabel independen mengalami perubahan. Adapun hasil pengujiannya sebagai berikut:

Tabel 5. Hasil Pengujian Regresi Linier Berganda Coefficients

\begin{tabular}{|c|c|c|c|c|c|c|}
\hline \multirow{2}{*}{\multicolumn{2}{|c|}{ Model }} & \multicolumn{2}{|c|}{$\begin{array}{l}\text { Unstandardized } \\
\text { Coefficients }\end{array}$} & \multirow{2}{*}{$\begin{array}{c}\text { Standardized } \\
\text { Coefficients } \\
\text { Beta }\end{array}$} & \multirow[b]{2}{*}{$\mathrm{t}$} & \multirow[b]{2}{*}{ Sig. } \\
\hline & & $\mathrm{B}$ & Std. Error & & & \\
\hline \multirow[t]{4}{*}{1} & (Constant) & .446 & 1.193 & & .374 & .709 \\
\hline & Kualitas Produk & .320 & .116 & .210 & 2.762 & .007 \\
\hline & Kualitas Informasi & .671 & .098 & .585 & 6.868 & .000 \\
\hline & $\begin{array}{l}\text { Kepercayaan } \\
\text { Pelanggan }\end{array}$ & .474 & .191 & .179 & 2.478 & .015 \\
\hline
\end{tabular}

a. Dependent Variable: Minat Beli

Berdasarkan hasil pengujian pada tabel di atas, diperoleh persamaan regresi $Y=0,446+0,320 \mathrm{X} 1+0,671 \mathrm{X} 2+$ 0,474 X3. Dari persamaan tersebut dijelaskan sebagai berikut:

1) Konstanta sebesar 0,446 artinya jika Kualitas Produk, Kualitas Informasi dan kepercayaan Pelanggan tidak ada maka Minat Beli sebesar 0,446

2) Koefisien Regresi Kualitas Produk sebesar 0,320 angka ini positif artinya setiap ada peningkatan Kualitas Produk sebesar 0,320 maka minat beli konsumen juga akan mengalami peningkatan sebesar 0,320

3) Koefisien Regresi Kualitas Informasi sebesar 0,671 angka ini positif artinya setiap ada peningkatan Kualitas Informasi sebesar 0,671 maka minat beli konsumen juga akan mengalami peningkatan sebesar 0,671

4) Koefisien Regresi Kepercayaan Pelanggan sebesar 0,474 angka ini positif artinya setiap ada peningkatan Kepercayaan Pelanggan sebesar 0,474 maka minat beli konsumen juga akan 
mengalami peningkatan sebesar 0,474

Analisis koefisien determinasi dimaksudkan untuk mengetahui besarnya persentase pengaruh dari variabel independen terhadap variabel dependen baik secara parsial maupun simultan. Adapun hasil pengujian sebagai berikut:

\section{Analisis Koefisien Determinasi}

Tabel 6. Hasil Pengujian Koefisien

Determinasi Kualitas Produk, Kualitas Informasi dan Kepercayaan Pelanggan

Model Summaryb

\begin{tabular}{|c|c|c|c|c|}
\hline Model & $\mathrm{R}$ & $\begin{array}{c}\mathrm{R} \\
\text { Square }\end{array}$ & $\begin{array}{c}\text { Adjusted R } \\
\text { Square }\end{array}$ & $\begin{array}{l}\text { Std. Error } \\
\text { of the } \\
\text { Estimate }\end{array}$ \\
\hline 1 & $.932^{a}$ & .869 & .865 & 2.35346 \\
\hline
\end{tabular}

b. Dependent Variable: Minat Beli

Dari persamaan tersebut dapat disimpulkan bahwa kualitas produk, kualitas informasi dan kepercayaan pelanggan terhadap minat beli berpengaruh positif dan signifikan sebesar $86,9 \%$, dan sisanya 13,1\% dipengaruhi oleh variabel lain yang tidak diteliti dalam penelitian ini.

\section{Uji Hipotesis}

\section{Uji hipotesis Parsial (Uji t)}

Pengujian hipotesis dengan uji $t$ digunakan untuk mengetahui hipotesis parsial mana yang diterima.

H1 : Kualitas produk (X1) berpengaruh positif dan signifikan secara parsial terhadap minat beli (Y) di Lazada.

$\mathrm{H} 2$ : Kualitas informasi (X2) berpengaruh positif dan signifikan secara parsial terhadap minat beli (Y) di Lazada.

H3 : Kepercayaan pelanggan (X3) berpengaruh positif dan signifikan secara parsial terhadap minat beli (Y) di Lazada.

$$
\text { Tabel 7. Hasil Uji t (parsial) }
$$

\section{Coefficients $^{a}$}

Unstandardized

Coefficients

\begin{tabular}{|c|c|c|c|c|c|c|}
\hline \multirow{2}{*}{\multicolumn{2}{|c|}{ Model }} & \multicolumn{2}{|c|}{ Coefficients } & \multirow{2}{*}{$\begin{array}{c}\text { Coefficients } \\
\text { Beta }\end{array}$} & \multirow[b]{2}{*}{$t$} & \multirow[b]{2}{*}{ Sig. } \\
\hline & & B & Std. Error & & & \\
\hline 1 & (Constant) & .446 & 1.193 & & .374 & .709 \\
\hline & Kualitas Produk & .320 & 116 & 210 & 2.762 & .007 \\
\hline & Kualitas Informasi & .671 & .098 & .585 & 6.868 & .000 \\
\hline & $\begin{array}{l}\text { Kepercayaan } \\
\text { Pelanggan }\end{array}$ & .474 & .191 & .179 & 2.478 & .015 \\
\hline
\end{tabular}

a. Dependent Variable: Minat Beli

Pada tabel 7, maka hasil uji $\mathrm{t}$ (parsial) sebagai berikut :

1. Pengaruh antara variabel kualitas produk terhadap minat beli adalah $\mathrm{t}$ hitung 2,762 $>\mathrm{t}$ tabel 1,988) atau sig 0,007 $<0,05$. dengan demikian hipotesis pertama yang diajukan bahwa terdapat pengaruh yang signifikan atara kualitas produk terhadap minat beli di Lazada

2. Pengaruh kualitas informasi terhadap minat beli adalah $\mathrm{t}_{\text {hitung }} 6,868>\mathrm{t}$ tabel 1,988 atau sig $0,000<0,05$. dengan demikian hipotesis kedua yang diajukan bahwa terdapat pengaruh yang signifikan atara kualitas informasi terhadap minat beli di Lazada
3. Pengaruh kepercayaan pelanggan terhadap minat beli $\mathrm{t}_{\text {hitung }} 2,478>\mathrm{t}_{\text {tabel }}$ 1,988 atau sig $0,015<0,05$. dengan demikian hipotesis ketiga yang diajukan bahwa terdapat pengaruh yang signifikan atara kepercayaan pelanggan terhadap minat beli di Lazada.

\section{Uji hipotesis Simultan (Uji F)}

Pengujian hipotesis dengan uji $\mathrm{F}$ digunakan untuk mengetahui hipotesis simultan yang mana yang diterima.

H4 : Kualitas produk (X1), Kualitas informasi (X2) dan Kepercayaan pelanggan (X3) berpengaruh positif dan signifikan secara simultan terhadap minat beli $(Y)$ di Lazada. 
Tabel 8. Hasil Uji F (simultan)

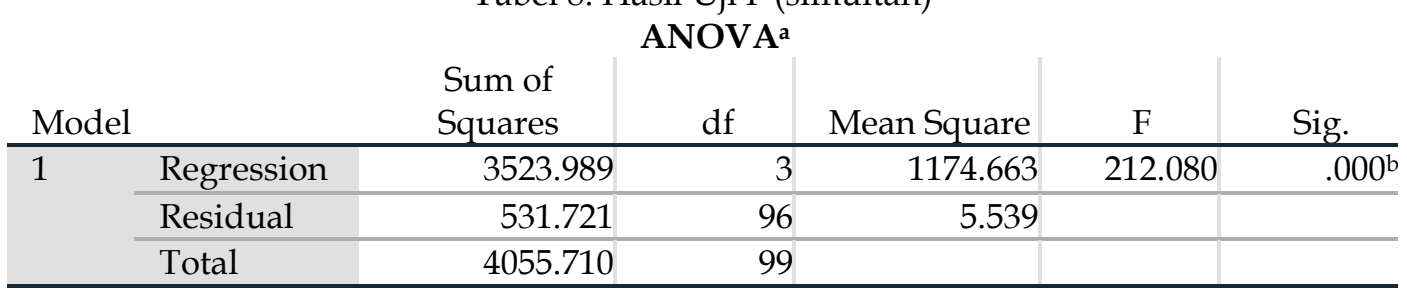

a. Dependent Variable: Minat Beli

b. Predictors: (Constant), Kepercayaan Pelanggan, Kualitas Produk, Kualitas Informasi

Berdasarkan hasil pengujian pada tabel di atas, diketahui nilai signifikan untuk variabel kualitas produk (X1), kualitas informasi (X2), dan kepercayaan pelanggan $(X 3)$ sebesar $0,000<0,05$ dan nilai $\mathrm{F}_{\text {hitung }} 212,080>\mathrm{F}_{\text {tabel }} 2,70$, sehingga $\mathrm{HO}$ ditolak dan Ha diterima. Dengan demikian hipotesis keempat yang diajukan bahwa terdapat pengaruh yang signifikan atara kualitas produk, kualitas informasi dan kepercayaan pelanggan terhadap minat beli di Lazada.

\section{Pembahasan Hasil Penelitian}

\section{Pengaruh Kualitas Produk Terhadap} Minat beli

Pengujian hipotesis memiliki pengaruh langsung yang menunjukan bahwa nilai variabel kualitas produk sebesar $0,000<0,05$. Dapat dilihat juga dari hasil perbandingan $t$ hitung dan $t$ tabel yang memiliki nilai $t_{\text {hitung }}$ sebesar 2,762 > 1,988. Dari hasil tersebut dapat disimpulkan bahwa $\mathrm{H} 1$ diterima dan $\mathrm{H} 0$ ditolak, karena hipotesis berada di daerah penerimaan maka variabel kualitas produk berpengaruh positif dan signifikan terhadap minat beli.

2. Pengaruh Kualitas Informasi Terhadap Minat Beli

Pengujian hipotesis memiliki pengaruh langsung yang menunjukan bahwa nilai variabel kualitas informasi sebesar $0,000<0,05$. Dapat dilihat juga dari hasil perbandingan $t$ hitung dan $t_{\text {tabel }}$ yang memiliki nilai $t_{\text {hitung }}$ sebesar 6,868 > 1,988. Dari hasil tersebut dapat disimpulkan bahwa $\mathrm{H} 1$ diterima dan $\mathrm{H} 0$ ditolak, karena hipotesis berada di daerah penerimaan maka variabel kualitas informasi berpengaruh positif dan signifikan terhadap minat beli.

3. Pengaruh Kepercayaan Pelanggan Terhadap Minat Beli

Pengujian hipotesis memiliki pengaruh langsung yang menunjukan bahwa nilai variabel kepercayaan pelanggan sebesar $0,000<0,05$. Dapat dilihat juga dari hasil perbandingan $t$ hitung dan $\mathrm{t}$ tabel yang memiliki nilai $\mathrm{t}$ hitung sebesar 2,478 > 1,988. Dari hasil tersebut dapat disimpulkan bahwa H1 diterima dan $\mathrm{HO}$ ditolak, karena hipotesis berada di daerah penerimaan maka variabel kepercayaan pelanggan berpengaruh positif dan signifikan terhadap minat beli.

4. Pengaruh Kualitas Produk, Kualitas Informasi, dan Kepercayaan Pelanggan Terhadap Minat Beli

Berdasarkan pengujian $\mathrm{F}$ (simultan) dihasilkan $\mathrm{F}$ hitung $>\mathrm{F}$ tabel yaitu 212,080 $>2,70$ dengan nilai signifikansi 0,000 $<0,05$ artinya H3 diterima dan H0 ditolak. hasil tersebut secara simultan menunjukan bahwa terdapat pengaruh signifikan antara variabel kualitas produk, kualitas informasi, dan kepercayaan pelanggan terhadap minat beli. Penelitian ini memiliki nilai koefisien determinasi sebesar 0,869 dimana angka tersebut mendekati 1 yang artinya memiliki pengaruh yang kuat dan berpengaruh secara simultan sebesar $86,9 \%$ sedangkan sisanya $13,1 \%$ dipengaruhi oleh variabel lain yang tidak diteliti dalam penelitian ini. Hasil tersebut menunjukan bahwa variabel kualitas produk, kualitas informasi, kepercayaan pelanggan terhadap minat beli memiliki pengaruh sebesar 
$86,9 \%$ dapat dikatakan jika variabel independen dalam penelitian ini menjadi salah satu faktor yang dapat meningkatkan minat beli.

\section{KESIMPULAN DAN SARAN Kesimpulan}

Berdasarkan hasil dan pembahasan yang telah dipaparkan pada bab IV, maka dapat ditarik kesimpulan sebagai berikut:

a. Penelitian pada variabel kualitas produk terhadap minat beli hasil menunjukkan bahwa terdapat pengaruh yang positif dan signifikan antara variabel kualitas produk terhadap minat beli.

b. Penelitian pada variabel kualitas informasi terhadap minat beli hasil menunjukkan bahwa terdapat pengaruh yang positif dan signifikan antara variabel kualitas informasi terhadap minat beli.

c. Penelitian pada variabel kepercayaan pelanggan terhadap minat beli hasil menunjukkan bahwa terdapat pengaruh yang positif dan signifikan antara variabel kepercayaan pelanggan terhadap minat beli.

d. Hasil penelitian pada variabel kualitas produk, kualitas informasi, dan kepercayaan pelanggan terhadap minat beli memiliki pengaruh yang positif dan signifikan secara simultan.

\section{Saran}

a. Untuk perusahaan adalah dalam meningkatkan kepercayaan pelanggan, perusahaan sebaiknya membangun kepercayaan dari pelanggan tidak hanya dengan kualitas tetapi juga dengan adanya hubungan pelanggan (customer relationship management) sehingga pelanggan memiliki koneksi dengan produk yang digunakannya. Tentunya jika hal tersebut dilakukan, maka minat beli juga akan meningkat.

b. Untuk peneliti selanjutnya adalah peneliti selanjutnya diharapkan untuk mengkaji lebih banyak sumber maupun referensi dengan pembahasan tersebut agar hasil penelitiannya dapat lebih baik dan lebih lengkap lagi serta diharapkan lebih mempersiapkan diri dalam proses pengambilan, pengumpumpulan dan segala sesuatunya sehingga penelitian dapat dilaksanakan dengan baik.

\section{DAFTAR PUSTAKA}

Agustini, N. K. D. A. (2017). Analisis FaktorFaktor Yang Mempengaruhi Keputusan Membeli Di Online Shop Mahasiswa Jurusan Pendidikan Ekonomi Angkatan Tahun 2012. Jurnal Pendidikan Ekonomi Undiksha, 9(1), 127. https://doi.org/10.23887/jjpe.v9i1.1 9997

Amil, B., Nasional, Z., BAZNAS, Badan, K., Zakat, A., Republik, N., د, غسان., Badan Amil Zakat Nasional, Dana, L. P. L. D. A. N., Keuangaii, L., Beraktiir, Y., Relief, H., Hall, J. K., Weinberger, R., Marco, S., Steinitz, G., Moula, S., Accountants, R. P., Report, A. A. S., ... Andhini, A., \& Khuzaini. (2017). Pengaruh transaksi online shopping, dan kepercayaan konsumen terhadap kepuasan konsumen pada ecommerce. Jurnal Ilmu Dan Riset Manajemen, 6(7), 1-23. http://jurnalmahasiswa.stiesia.ac.id /index.php/jirm/article/view/1753 /1763

Anwar, R., \& Adidarma, W. (2016). Pengaruh Kepercayaan dan Risiko Pada Minat Beli Belanja Online. Jurnal Manajemen Dan Bisnis Sriwijaya, 14(2), 155-168.

https://doi.org/10.29259/jmbs.v14i2 .3995

Arum, D. L. (2013). Pengaruh Kepercayaan Dan Kualitas Website Terhadap Sikap Pelanggan Serta Dampaknya Terhadap Minat Beli Konsumen Pada Toko Online "My Sorella." 1-44.

Bahar, A., \& Sjahruddin, H. (2017). pengaruh Kualitas Produk Dan Kualitas Pelayanan Terhadap Kepuasan Konsumen Dan Minat Beli Ulang. 3, 14-34.

Bahrudin, M., \& Zuhro, S. (2016). Pengaruh Kepercayaan Dan Kepuasan Pelanggan Terhadap Loyalitas Pelanggan. BISNIS : Jurnal Bisnis Dan 
Manajemen Islam, 3(1), 1. https://doi.org/10.21043/bisnis.v3i1 .1463

Eddy, S. A. (2020). Pengaruh Persepsi Harga Dan Kepercayaan Terhadap Minat Beli Secara Online Saat Pandemi Covid-19 Pada Masyarakat Millenia Di Jawa Tengah. Journal of Chemical Information and Modeling, 21(1), 1-9. https://doi.org/10.1016/j.tmaid.2020 .101607\%0Ahttps://doi.org/10.1016/ j.ijsu.2020.02.034\%0Ahttps://onlineli brary.wiley.com/doi/abs/10.1111/cj ag.12228\%0Ahttps://doi.org/10.1016 /j.ssci.2020.104773\%0Ahttps://doi.or g/10.1016/j.jinf.2020.04.011\%0Ahttps ://doi.o

Erlangga, H, et al. (2019). Pengaruh Kegiatan Promosi Terhadap Keputusan Pembelian Konsumen Pada PT. Modise Busana Sejati Di Bandung. Jurnal Ekonomi Efektif, 1(4).

Erlangga, H. (2021). Effect Of Digital Marketing And Social Media On Purchase Intention Of Smes Food Products. Turkish Journal of Computer and Mathematics Education (TURCOMAT), 12(3), 3672-3678.

Erlangga, H., et al. (2020). Pharmaceutical Business Competition in Indonesia: A Review. Systematic Reviews in Pharmacy, 11(10), 617-623.

Gunawan, H., \& Ayuningtiyas, K. (2018). Pengaruh Kepercayaan, Kemudahan Dan Kualitas Informasi Terhadap Keputusan Pembelian Daring Di Aplikasi Bukalapak Pada Mahasiswa Politeknik Negeri Batam. Journal of Applied Business Administration, 2(1), 152-165.

https://doi.org/10.30871/jaba.v2i1.7 63

Hardiawan, A. C. (2013). Pengaruh Kepercayaan, Kemudahan, dan Kualitas Informasi Terhadap Keputusan Pembelian Secara Online (Studi Pada Pengguna Situs Jual Beli Online tokobagus.com ). Pengaruh Kepercayaan,Kemudahan,Dan Kualitas Informasi Terhadap Keputusan Pembeli
Secara Online, 90.

Kasmad, K., Mustakim, M., \& Sunarsi, D. (2020). Increasing Community School Interest Through Service Quality, Prices and Promotion in Vocational High Schools. Journal of Educational Science and Technology (EST), 6(2).

Maddinsyah, A., et al. (2020). Desain Formulasi Dan Implementasi Bisnis Strategik Dengan Pendekatan Business Model Canvas (BMC) Terintegrasi Kerangka Integrated Performance Management System (IPMS) Pada Koperasi Asperindo. Inovasi, 7(2), 67-76.

Mulyadi, A., Eka, D., \& Nailis, W. (2018). Pengaruh Kepercayaan, Kemudahan, Dan Kualitas Informasi Terhadap Keputusan Pembelian Di Toko Online Lazada. Jembatan, 15(2), 87-94. https://doi.org/10.29259/jmbt.v15i2. 6656

Nurjaya, N., et al. (2021). The Effect of Product Promotion and Innovation Activities on Marketing Performance in Middle Small Micro Enterprises in Cianjur. Budapest International Research and Critics Institute (BIRCIJournal): Humanities and Social Sciences, $4(1), 528-540$.

Purwanto, A., et al. (2021). The Role of Brand Image, Food Safety, Awareness, Certification on Halal Food Purchase Intention: An Empirical Study on Indonesian Consumers. Journal of Industrial Engineering $\mathcal{E}$ Management Research, 2(3), 42-52.

Rachmawati, I. K., Handoko, Y., Nuryanti, F., Wulan, M., \& Hidayatullah, S. (2019). Pengaruh Kemudahan, Kepercayaan Pelanggan Dan Kualitas Informasi Terhadap Keputusan Pembelian Online. Seminar Nasional Sistem Informasi 2019, 3(September), 1617-1625.

Rahmadani., S. F. Makalah_Struktur_Tulang.

(2015).

Rinaldi, A., \& Santoso, S. B. (2018). Analisis Pengaruh Kualitas Informasi, Kualitas Sistem dan Kualitas Pelayanan 
terhadap Minat Beli Ulang dengan Kepuasan Pelanggan sebagai Variabel Intervening. Diponegoro Journal of Management,7(2),1-14.

https:// ejournal3.undip.ac.id/index. php/djom/article/view/20901

Rohimah, S. A. S., \& Pradini3, S. (2019). HUBUNGAN POLA ASUH OTORITATIF TERHADAP KEMANDIRIAN ANAK USIA 5-6 TAHUN. 1.

Sari, H., \& Setiaboedhi, A. P. (2017). FaktorFaktor Yang Memengaruhi Minat Beli Pangan Organik Melalui Situs Online. Jurnal Manajemen Dan Agribisnis, 14(1), 54-64. https://doi.org/10.17358/jma.14.1.54

Sugiyono. (2016). Metode Penelitian Administrasi. Alfabeta.

Sugiyono. (2017). Metode Penelitian Kombinasi. Alfabeta.

Suparwo, adi, \& Pratama, agriya fanny. (2021). Pengaruh Advertising Dan Harga Penjualan Paket Umrah Plus Wisata Terhadap Minat Beli. Jurnal Sain Manajemen, 3(1).

Sutrisno, N., \& Haryani, A. D. (2017). Pengaruh Harga, Promosi, Dan Kualitas Produk Terhadap Minat Beli
Konsumen Pada Perusahaan A-36. Jurnal Lentera Bisnis, 6(1), 85. https://doi.org/10.34127/jrlab.v6i1.1 69

Syobar, K., et al. (2020). The Effect of Service Quality and Price on Purchase Decisions in Woodpecker Coffee in South Jakarta. Solid State Technology, 63(6), 1491-1504.

Widiani, N. L. M., Indiani, N. L. P., \& Wahyuni, N. M. (2020). Pengaruh Citra Merek Dan Kualitas Informasi Terhadap Minat Konsumen Berbelanja Kembali Di Zalora. Jurnal Ilmiah Manajemen Dan Bisnis, 2(2), 127. https://doi.org/10.38043/jimb.v2i2.2 337

Wijaya, C., \& Kempa, S. (2018). Terhadap Kepuasan Konsumen Melalui Keputusan Pembelian Produk Fashion Di Lazada. AGORA Vol. 6, No. 2 (2018), 6(2), 1-6.

Yazia, V. (2014). Pengaruh Kualitas Produk, Harga dan Iklan terhadap Keputusan Pembelian Handphone Blackberry. Journal of Economic and Economic Education, 2(2), 165-173. http://dx.doi.org/10.22202/economi ca.2014.v2.i2.229 